\title{
Adrian Zbrojewski
}

\section{Glosa aprobująca do postanowienia Sądu Najwyższego z 26.1.2017 r. (sygn. akt I CSK 54/16)}

Glosa odnosi się do orzeczenia Sądu Najwyższego rozstrzygającego, że w przypadku sądowego podziału majątku wspólnego, sąd ustalając wartość składnika majątku obciążonego hipoteką, nie uwzględnia obniżenia wartości rynkowej składnika spowodowanego obciążeniem. Prezentując analizę oraz ocenę argumentów przedstawionych przez Sąd Najwyższy, Autor odwołuje się także do poglądów doktrynalnych oraz przedstawia własne argumenty przemawiające za trafnością poglądu przyjętego w glosowanym orzeczeniu.

Communio est mater rixarum ${ }^{1}$

\section{Wstęp}

Postępowania działowe, do których należy zaliczyć postępowanie o zniesienie współwłasności rzeczy, o dział spadku oraz o podział majątku wspólnego małżonków występują powszechnie i przynajmniej potencjalnie mogą dotyczyć każdego. Nierzadko cechuje je silna sprzeczność interesów ich uczestników, która uniemożliwia dokonanie umownego podziału rzeczy czy majątku stanowiącego przedmiot wspólności. W konsekwencji wskazanego stanu rzeczy stosunkowo często podział następuje poprzez sądowe przyznanie określonego składnika bądź składników majątku jednemu z uczestników, $\mathrm{z}$ nałożeniem na niego obowiązku spłaty pozostałych na podstawie art. $212 \S 2$ kodeksu cywilnego ${ }^{2}$ stosowanego wprost albo odpowiednio poprzez odesłania zawarte w art. 1035 k.c. oraz art. 46 kodeksu rodzinnego i opiekuńczego 3 .

Podstawową czynnością dokonywaną przez sąd w ramach wskazanego wyżej sposobu podziału jest ustalenie wartości przedmiotów mu podlegających, które wraz z wielkością udziałów w rzeczy objętej współwłasnością albo w majątku wspólnym, warunkują wysokość spłaty należnej innym uczestnikom. Dokonanie powyższego nie zawsze

\footnotetext{
1 „Współwłasność jest źródłem sporów”.

${ }^{2}$ Ustawa z 23.4.1964 r. - Kodeks cywilny, tekst jedn.: Dz. U. z 2017 r., poz. 459 ze zm. Dalej jako: k.c.

${ }^{3}$ Ustawa z 25.2.1964 r. - Kodeks rodzinny i opiekuńczy, tekst jedn.: Dz.U. z 2017 r., poz. 682. Dalej jako: k.r.i.o.
} 
stanowi proste zadanie, czego najlepszym dowodem jest orzeczenie będące przedmiotem niniejszej glosy.

\section{Stan faktyczny}

Stan faktyczny, na kanwie którego zapadło komentowane postanowienie Sądu Najwyższego ${ }^{4}$, był dosyć typowy. Sprawa dotyczyła podziału majątku wspólnego małżonków obejmującego szereg różnych składników majątkowych. Punktem centralnym sporu stało się ustalenie wartości spółdzielczego własnościowego prawa do lokalu mieszkalnego ${ }^{5}$, nabytego za środki pochodzące z niespłaconego w dniu orzekania kredytu zaciągniętego wspólnie przez małżonków, które było obciążone hipoteką na rzecz banku.

Sąd I instancji przyznał prawo do wskazanego wyżej mieszkania na rzecz jednego z małżonków zobowiązując go do spłaty udziału drugiego małżonka. Za wartość miarodajną do dokonania rozliczeń między byłymi małżonkami uznano „rynkową wartość” mieszkania, która została ustalona z pominięciem obciążenia hipotecznego. Uczestnik, na którego został nałożony obowiązek spłaty, w apelacji, jak i następnie w skardze kasacyjnej podnosił, że wartości mieszkania stanowiąca podstawę do rozliczeń powinna zostać pomniejszona o obciążenie hipoteczne. Ani sąd II instancji, ani SN, nie uwzględniły jednak wskazanego zarzutu.

\section{Orzeczenie Sądu Najwyższego}

Uzasadniając swoje rozstrzygnięcie SN oparł się na kilku założeniach ogólnych. Za najistotniejsze w kontekście zagadnienia będącego przedmiotem sporu należy uznać stwierdzenia, że sąd w postępowaniu działowym może dzielić wyłącznie aktywa (nie może natomiast dokonywać podziału lub rozliczenia niespłaconych jeszcze długów) oraz, że wartość nieruchomości ulegającej podziałowi powinna być oceniana według wartości rynkowej ocenianej na dzień orzekania. Pojęcie tej ostatniej zostało zdefiniowane przez SN jako najbardziej prawdopodobna cena, możliwa do uzyskania na rynku. Uprzedzając zarzut, że wartości rynkowe mieszkania obciążonego hipotecznie wolnego od takiego obciążenia różnią się od siebie, w dalszej części uzasadnienia odwołano się do praktyki obrotu nieruchomościami, w ramach której nabywca nieruchomości obciążonej hipotecznie

\footnotetext{
${ }^{4}$ Dalej jako „SN”.

5 Dalej jako „mieszkanie”.
} 
przekazuje część wartości rynkowej nieruchomości wierzycielowi hipotecznemu celem zaspokojenia jego wierzytelności względem zbywającego nieruchomość, co z kolei powoduje wygaśnięcie hipoteki. Powyższe zdaniem SN prowadzi do wniosku, że obciążenie hipoteką nie wywiera wpływu na wartość rynkową nieruchomości, lecz jedynie na sposób rozliczenia jej sprzedaży, której cena opiewa na wartość rynkową nieruchomości (niepomniejszoną o obciążenie hipoteczne), a której zapłata następuje do dwóch różnych podmiotów.

Odnosząc się do powyższego należy zgodzić się z SN, że zakres kognicji sądu w postępowaniu działowym obejmuje wyłącznie podział aktywów, choćby z tej prostej przyczyny, że przyjęcie odmiennego zapatrywania jest pozbawione podstawy prawnej6 Ponadto rudymentarne argumenty funkcjonalne czynią koniecznym przyjęcie, że podział nie może odnosić się do zobowiązań, których stronami są także podmioty trzecie nieuczestniczące $\mathrm{w}$ postępowaniu działowym ${ }^{7}$. Za dyskusyjne należy natomiast uznać stwierdzenie, że nieruchomość obciążona hipotecznie jest w istocie zbywana za „pełną cenę”. Z przytoczonej wyżej definicji wartości rynkowej wyraźnie wynika, że wartością tą jest cena możliwa do uzyskania na rynku. Przyjmując natomiast praktykę obrotu, na którą wskazał Sąd, należy stwierdzić, że zbycie nieruchomości przez dłużnika rzeczowego nie doprowadzi do uzyskania przez niego ceny równej pełnej wartości nieruchomości. Uzyskanie części „,ceny” przez bank nie następuje przecież w ramach sprzedaży nieruchomości, ponieważ bank nie jest jej stroną. Ponadto praktyka obrotu nieruchomościami, na którą wskazał SN, nie wyklucza możliwości wystąpienia sytuacji, w której doszłoby do nabycia nieruchomości obciążonej hipotecznie za cenę obniżoną o wartość obciążenia hipotecznego, bez uiszczenia jakichkolwiek sum na rzecz banku. Należy więc przyjąć, że ostatnio wskazana wartość stanowi w tym przypadku wartość rynkową. Przytoczony wyżej fragment glosowanego postanowienia należy więc uznać za wewnętrznie sprzeczny ${ }^{8}$.

Powyższe nie przekreśla jednak prawidłowości zawartego w nim rozstrzygnięcia. Za konieczne należy bowiem uznać ustalenie czy rzeczywiście w przypadku składników majątkowych obciążonych hipotecznie, to właśnie wartość rynkowa z chwili orzekania o dziale

\footnotetext{
${ }^{6}$ Pogląd należy uznać za powszechnie przyjęty. Zob. E. Skowrońska-Bocian, Rozliczenia majątkowe matżonków w stosunkach wzajemnych $i$ wobec osób trzecich, Warszawa 2010, s. 224 wraz z przytoczoną tam literaturą.

${ }^{7}$ Poglądy w tym zakresie zbiera J. Styk [w:] Kodeks rodzinny i opiekuńczy. Komentarz. Przepisy wprowadzajace $K R O$, red. K. Osajda, Warszawa 2017, s. 505.

${ }^{8}$ Rozumowania SN można bronić odwołując się do konstrukcji przekazu uregulowanej w art. $921^{1}-921^{5}$ k.c., w ramach którego przekazujący (zbywca nieruchomości obciążonej hipoteką) upoważnia przekazanego (nabywcę nieruchomości obciążonej) do spełnienia świadczenia (,,spłacenia hipoteki”) na rzecz odbiorcy przekazu (banku wierzyciela hipotecznego). Należy jednak zauważyć, że wartość rynkowa w tym ujęciu będzie różna w zależności od tego, czy nabywca nieruchomości zdecyduje się na spłacenie obciążenia hipotecznego czy też nie.
} 
powinna stanowić wartość relewantną dla ustalania spłaty drugiego małżonka? Należy bowiem zauważyć, że wartość mieszkania obciążonego hipoteką może być zmienna w czasie. W okresie, w którym nieruchomość jest obciążona hipotecznie cena jej nabycia będzie niższa od normalnej wartości rynkowej. Hipoteka nie ma jednak charakteru permanentnego i w momencie wykonania zabezpieczonego nią zobowiązania wygasa, umożliwiając zbywcy uzyskanie ,pełnej” ceny.

Przed przejściem do analizy szczegółowej argumentacji SN, w tym miejscu należy wskazać, że komentowane rozstrzygnięcie stanowi odejście od ugruntowanej linii orzeczniczej przyjmującej wprost albo obiter dicta, że w sprawie o podział majątku wspólnego przydzielając jednemu z uczestników nieruchomość obciążoną hipoteką - sąd ustala wartość tego składnika majątkowego przy uwzględnieniu obciążenia hipotecznego - tzn. dokonuje odpowiedniego pomniejszenia jego wartości ${ }^{9}$.

Uzasadniając przytoczony pogląd wskazuje się, że pomniejszenie wartości nieruchomości o obciążenie hipoteczne ma na celu zapobieżenie sytuacji, w której podmiot, któremu przyznano składnik majątkowy byłby zobowiązany do „dwukrotnego płacenia”. Powyższe odnosi się do stanów faktycznych, w których uczestnik w związku z postępowaniem działowym spłacił udział drugiego współwłaściciela według wartości nieruchomości niepomniejszonej o obciążenie hipoteczne, a nadto - działając następnie w celu uniknięcia egzekucji z nieruchomości - został faktycznie zmuszony do zapłaty całości kredytu, za który odpowiada rzeczowo. $\mathrm{Z}$ powyższym powiązany jest oparty na art. $618 \S 3$ kodeksu postępowania cywilnego ${ }^{10}$ pogląd, że po zapadnięciu prawomocnego postanowienia działowego nie można dochodzić roszczeń rozliczeniowych - w tym roszczeń z tytułu spłacenia całej wierzytelności zabezpieczonej hipoteką ${ }^{11}$. W konsekwencji wskazuje się, że ostateczne rozliczenie między uczestnikami powinno nastąpić w postanowieniu kończącym postępowanie

\footnotetext{
${ }^{9}$ Zob. post. SN z 6.7.1970 r., III CRN 156/70, OSNCP 1971, Nr 4, poz. 71; post. SN z 30.12.1971 r., III CRN 396/71, OSNCP 1972, Nr 7-8, poz. 134; uchw. SN z 19.12.1978 r., III CZP 80/78, OSNCP 1979, Nr 9, poz. 162; post. SN z 5.10.2000 r., II CKN 611/99, Monitor Prawniczy 2001, Nr 2, s. 93; wyr. SN z 2.4.2003 r., III RN 52/02, OSP 2005, Nr 3, poz. 32; post. SN z 29.9.2004 r., II CK 538/03, Legalis; uchw. SN z 25.6.2008 r., III CZP 58/08, OSNC 2009, Nr 7-8, poz. 99; post. SN z 21.1.2010 r., I CSK 205/09, Legalis; post. SN z 20.4.2011 r., I CSK 661/10, OSNC-ZD 2012, Nr B, poz. 31. Wskazany pogląd jest również aprobowany przez zdecydowaną większość doktryny. Zob. E. Skowrońska-Bocian, Rozliczenia majątkowe..., s. 230-231, A. Stempniak, Autonomia i integracja postępowań działowych $w$ prawie polskim, Warszawa 2017, s. 549 wraz z licznie wskazaną tam literaturą oraz K. Skiepko [w:] Komentarz do spraw o podziat majątku wspólnego małżonków, red. J. Ignaczewski, Warszawa 2017, s. 258-263.

${ }^{10}$ Ustawa z 17.11.1964 r. - Kodeks postępowania cywilnego, tekst jedn.: Dz. U. z 2018 r., poz. 155 ze zm. Dalej jako: k.p.c. Artykuł $618 \S 3$ k.p.c. jest stosowany do spraw o podział majątku wspólnego poprzez odesłania zawarte w art. $567 \S 3$ k.p.c. w zW. z art. 688 k.p.c.

11 Zob. post. SN z 2.4.2009 r., IV CSK 566/08, Monitor Prawniczy 2009, nr 9, s. 466 oraz A. Stempniak, Autonomia i integracja..., s. 549.
} 
działowe, co z kolei wymaga pomniejszenia wartości przyznawanego z obowiązkiem spłaty składnika majątkowego o obciążenie hipoteczne. W przeciwnym wypadku uczestnik, któremu przyznano obciążony składnik majątkowy, mógłby zostać zmuszony do „podwójnej zapłaty” bez możliwości dochodzenia roszczeń zwrotnych z uwagi na wskazaną wyżej prekluzję. W tym ujęciu przyznanie nieruchomości obciążonej hipotecznie jednemu z uczestników czyni go (faktycznie) wyłącznie zobowiązanym z tytułu kredytu, mimo że oboje małżonkowie pozostają nadal dłużnikami osobistymi banku.

Zaprezentowana wyżej argumentacja została podniesiona w skardze kasacyjnej oraz zreferowana w glosowanym postanowieniu. SN przeciwstawił jej następujące kontrargumenty.

Po pierwsze, w uzasadnieniu wskazano, że przyznanie obciążonego przedmiotu w postępowaniu działowym o obniżonej wartości nie jest skutecznym w sensie prawnym obciążeniem z tytułu umowy kredytu wyłącznie tego uczestnika, któremu przyznano wskazany przedmiot. Solidarne zobowiązanie drugiego uczestnika (na rzecz którego zasądzono spłatę) wobec banku pozostaje bowiem nadal w mocy i może być skutecznie dochodzone. Konsekwencją wskazanego stanu rzeczy może być powstanie sytuacji, w której wskazany uczestnik będzie zmuszony do spłacania całości kredytu, mimo że nie otrzymał ani nieruchomości, ani spłaty w pełnej wysokości. Bank dysponuje bowiem swobodą wyboru W zakresie dłużnika solidarnego, od którego będzie dochodził zaspokojenia. W takiej sytuacji uczestnik będzie mógł uzyskać zaspokojenie części swoich praw dopiero na etapie regresu wobec uczestnika, któremu przyznano składnik majątkowy (art. 376 k.c.).

Po drugie, przyjęcie poglądu przywołanego przez skarżącego rodzi konieczność antycypowania jak w przyszłości będzie przebiegała realizacja zobowiązania z tytułu umowy kredytu, co nie należy do kognicji sądu działowego, a ponadto - z uwagi na niepewność co do zdarzeń przyszłych - jest niemożliwe do ustalenia.

Po trzecie, SN zwrócił uwagę na istotne trudności dotyczące ustalenia wartości przedmiotu majątkowego pomniejszonego o obciążenie hipoteczne, jeżeli zabezpieczony rzeczowo kredyt jest wyrażony w walucie obcej, a jego raty uzależnione od zmieniających się kursów walut (tak jak w rozstrzyganej sprawie).

Po czwarte, w uzasadnieniu postanowienia wskazano, że prekluzja wynikająca z art. 618 § 3 k.p.c. nie znajduje zastosowania, jeżeli po podziale majątku wspólnego jeden z byłych małżonków dokonał spłaty solidarnego zobowiązania ciążącego na obu małżonkach. Zdaniem SN, kluczowym argumentem przemawiającym za poprawnością wskazanej tezy jest fakt, że dokonany dział nie wywiera wpływu na zobowiązania zaciągnięte wspólnie 
w czasie trwania wspólności ustawowej, które należy oceniać według przepisów k.c. o zobowiązaniach solidarnych.

Zaprezentowane wyżej argumenty doprowadziły SN do konkluzji, że właściwą metodą ustalenia wartości mieszkania wchodzącego w skład majątku wspólnego jest uwzględnienie jego wartości niepomniejszonej o obciążenie hipoteczne. Sąd zaznaczył jednak, że obie wskazane wyżej koncepcje mogą prowadzić do narażenia któregoś z małżonków na konieczność spłacania kredytu ponad udział, z czym małżonkowie muszą się liczyć rezygnując z umownego podziału majątku wspólnego.

\section{Komentarz}

Podejmując próbę oceny rozstrzygnięcia SN należy przede wszystkim zgodzić się ze stwierdzeniem, że obie zaprezentowane wyżej metody ustalania wartości składnika majątkowego obciążonego hipoteką nie są wolne od zastrzeżeń. Wybór między nimi jest trudnym zadaniem, czego najlepszym dowodem jest odejście w komentowanym orzeczeniu od przyjmowanej przez wiele lat linii orzeczniczej ${ }^{12}$.

Rozumowanie SN w sprawie w znacznej mierze zasadza się na krytyce poglądu przeciwnego, na którym została oparta skarga kasacyjna. W konsekwencji powyższego wywód zawarty w uzasadnieniu nie dość wyraźnie prezentuje argumenty przemawiające za przyjętą W orzeczeniu metodą ustalania wartości.

Z uzasadnienia płynie jednak bardzo istotny wniosek, który stanowi klucz do ustalenia, która z metod powinna być stosowana. W orzeczeniu trafnie bowiem wskazano, że w ramach postępowania działowego, sąd nie jest uprawniony do orzekania o zobowiązaniach. Ściśle związane z powyższym jest odrzucenie zdecydowanie błędnego poglądu jakoby art. 618 § 3 k.p.c. wykluczał możliwość późniejszych rozliczeń związanych ze spłatą kredytu (również poprzez zaspokojenie się banku z przedmiotu hipoteki) między byłymi małżonkami. Można więc stwierdzić, że niezależnie od faktycznego przebiegu zdarzeń w przyszłości, roszczenia z tytułu spłaty kredytu będą mogły zostać rozliczone na zasadach ogólnych prawa cywilnego - a więc m.in. w oparciu o przepisy dotyczące zobowiązań solidarnych.

\footnotetext{
${ }^{12}$ Metoda przyjęta w glosowanym postanowieniu została także przyjęta w późniejszym post. SN z 14.3.2017 r., II CZ 161/16, LEX nr 2334884.
} 
Co istotne, poczyniony przed chwilą wniosek jest aktualny w przypadku obu metod ustalania wartości przedmiotu obciążonego hipoteką ${ }^{13}$.

Poszukując punktu zaczepienia pozwalającego na przesądzenie, która z metod jest właściwa, należy odnieść się do istoty sądowego podziału majątku wspólnego. Celem wskazanego postępowania jest niewątpliwie dokonanie podziału majątku wspólnego w taki sposób, aby aktywa uzyskane przez każdego z małżonków odzwierciedlały ich udziały W majątku wspólnym, które co do zasady są równe (art. 43 § 1 k.r.i.o.). W konsekwencji wskazanego stanu rzeczy sąd orzekającw postępowaniu działowym o przyznaniu określonego aktywu jednemu z małżonkówz obowiązkiem spłaty drugiego powinien dążyć do zachowania równowagi między interesami uczestników. Błędny wybór metody ustalania wartości przedmiotu majątkowego podlegającego podziałowi może prowadzić do zaburzenia wskazanej równowagi. Powyższe prowadzi do wniosku, że kluczowe dla ustalenia prawidłowej wartości aktywu obciążonego hipoteką, jest dokonanie analizy ekonomicznych konsekwencji wyboru każdej z metod.

Wskazana analiza nie powinna jednak polegać na antycypacji pojedynczego zdarzenia, przykładowo: niespłacenia kredytu i zaspokojenia się przez bank z przedmiotu hipoteki, który to sposób rozumowania trafnie został odrzucony przez SN. Chodzi w tym przypadku o wariantowe określenie najbardziej prawdopodobnych konsekwencji zastosowania każdej z metod, które pozwoli na określenie, która z nich daje szanse na bardziej równomierne podzielenie majątku wspólnego w większej liczbie przypadków.

W pierwszej kolejności należy przeanalizować skutki zastosowania każdej $\mathrm{z}$ metod w sytuacji dobrowolnego spłacenia kredytu po wydaniu postanowienia działowego. Należy przyjąć, że bez znaczenia pozostaje który z małżonków spłacił kredyt w całości bądź W większej części, bowiem w tym zakresie rozliczenia (regres) następują na podstawie przepisów o zobowiązaniach solidarnych (a ściślej art. 376 k.c.). Ostatnio wskazana kwestia jest więc irrelewantna z punktu widzenia podziału majątku wspólnego.

Należy stwierdzić, że zastosowanie metody ustalania wartości przedmiotu majątkowego nieuwzględniającej obciążenia hipotecznego - przy założeniu, że kredyt zostanie spłacony gwarantuje równy podział pełnej wartości mieszkania między małżonków. W szczególności w takiej sytuacji straty nie poniesie małżonek, na rzecz którego przyznano spłatę.

\footnotetext{
${ }^{13}$ W szczególności należy podkreślić, że zastosowanie w postanowieniu kończącym postępowanie działowe metody określającej wartość nieruchomości obniżonej o obciążenie hipoteczne nie wyłącza stosowania ogólnych zasad rozliczeń wynikających m.in. z art. 376 k.c. Te ostatnie odnoszą się bowiem do sfery długów, orzekanie o których leży poza zakresem kognicji sądu działowego.
} 
Wskazana metoda będzie jednak niekorzystna dla małżonka, na rzecz którego przyznano mieszkanie, w tym sensie, że chcąc zbyć wskazany składnik majątkowy obciążony hipoteką, nie uzyska on pełnej wartości mieszkania. Należy jednak zauważyć, że opisany stan rzeczy ma charakter przejściowy, ponieważ po spłacie kredytu i wygaśnięciu hipoteki, wartość mieszkania wzrośnie. Ponadto małżonek, na rzecz którego przyznano mieszkanie, może wstrzymać się ze sprzedażą mieszkania do czasu spłaty kredytu.

Metoda ustalania wartości przedmiotu majątkowego uwzględniająca obciążenie hipoteczne usuwa natomiast problem niemożności sprzedania mieszkania obciążonego hipoteką w zamian za jego pełną wartość w czasie, w którym kredyt nie jest jeszcze spłacony. Należy jednak zauważyć, że w przypadku zbycia mieszkania po spłaceniu kredytu, małżonek, którego spłata została ustalona w oparciu o wartość pomniejszoną o obciążenie hipoteczne, nie uzyska połowy ceny, za którą mieszkanie zostało zbyte (lecz połowę wartości pomniejszonej o obciążenie hipoteczne), co może okazać się dla niego bardzo niekorzystne.

W tym miejscu należy przejść do analizy skutków wyboru każdej $\mathrm{z}$ metod w sytuacji, w której umowa kredytu nie zostanie wykonana dobrowolnie. Zdaniem autora niniejszej glosy nie ma podstaw do przyjmowania (tak jak uczynił to SN), że w braku innych zabezpieczeń bank nie zaspokoi się z przedmiotu majątkowego obciążonego hipoteką, która niesie dla niego podstawową korzyść w postaci pierwszeństwa zaspokojenia banku przed wierzycielami osobistymi małżonka, któremu przyznano mieszkanie (art. 65 ust. 1 ustawy o księgach wieczystych i hipotece ${ }^{14}$ ). Analizując konsekwencje zastosowania obu metod obliczania wartości przedmiotu majątkowego obciążonego hipoteką należy więc przyjmować, że małżonek, któremu przyznano mieszkanie, będzie odpowiadał rzeczowo względem banku.

W przypadku metody ustalania wartości nieuwzględniającej hipoteki powyższe prima facie będzie prowadziło do ,podwójnego płacenia” przez małżonka, któremu przyznano mieszkanie - raz na rzecz drugiego małżonka połowy pełnej ceny mieszkania (w ramach spłaty zasądzonej przez sąd $\mathrm{W}$ postępowaniu działowym); drugi raz na rzecz banku. Należy jednak zauważyć, że w przypadku zaspokojenia się z przedmiotu hipoteki przez bank (poprzez jego zbycie w postępowaniu egzekucyjnym) małżonek, któremu przyznano mieszkanie uzyskuje na podstawie art. 376 § 1 k.c. roszczenie regresowe względem drugiego małżonka. Powyższe oznacza, że w istocie małżonek, któremu przyznano mieszkanie

\footnotetext{
${ }^{14}$ Ustawa z 6.7.1982 r. o księgach wieczystych i hipotece, tekst jedn. Dz. U. z 2018 r., poz. 1916.
} 
z obowiązkiem spłaty płaci jednokrotnie -wyłącznie w ramach spłaty drugiego małżonka określonej w postępowaniu działowym.

Stosując metodę uwzględniającą obciążenie hipoteczne należy z kolei zauważyć, że w istocie prowadzi ona do nieuzasadnionego uprzywilejowania małżonka, na którego nakładany jest obowiązek spłaty. W przypadku braku spłaty kredytu i zaspokojenia się przez bank z przedmiotu hipoteki, małżonek ten bowiem również - na podstawie art. $376 \S 1$ k.c. będzie mógł dochodzić roszczenia regresowego od drugiego małżonka. Powyższe oznacza, że małżonek, na rzecz którego zasądzono spłatę, będzie dwukrotnie ponosił ciężar ekonomiczny zabezpieczenia kredytu hipoteką - raz na etapie ustalania wartości należnej mu spłaty (pomniejszonej o obciążenie hipoteczne) - drugi raz z tytułu roszczenia regresowego.

Mając na uwadze poczynioną wyżej analizę należy stwierdzić, że metoda ustalania wartości przedmiotu majątkowego nieuwzględniająca obciążenia hipotecznego prowadzi do zdecydowanie bardziej równomiernego podziału majątku wspólnego małżonków zarówno w sytuacji dobrowolnego spłacenia przez nich kredytu (powodującego wygaśnięcie hipoteki), jak i jego niespłacenia skutkującego zaspokojeniem się banku z przedmiotu hipoteki. Należy więc stwierdzić, że SN dokonał wyboru lepszej z metod ustalania wartości przedmiotu obciążonego hipoteką. Przeciwstawienie się funkcjonującej wcześniej jednolitej linii orzeczniczej powinno budzić tym większe uznanie. Co prawda uzasadnienie rozstrzygnięcia zawiera braki argumentacyjne, na które wskazano wyżej, jednak można zrozumieć, że zadaniem sądu w sprawie była przede wszystkim ocena zarzutów zawartych w skardze kasacyjnej. W tym zakresie SN celnie ,wypunktował” koncepcję prezentowaną dotychczas w orzecznictwie.

Za trafne należy uznać także stwierdzenie sądu, że $\mathrm{z}$ obiema prezentowanymi koncepcjami wiążą się pewne wady. Powyższe jest w znacznej mierze spowodowane brakiem wiedzy co do przyszłego realizowania zobowiązania kredytowego przez byłych małżonków. $\mathrm{Z}$ tej przyczyny poczyniona w niniejszej glosie wariantowa analiza jest oczywiście tylko próbą zracjonalizowania oceny obu metod ustalania wartości przedmiotu majątkowego obciążonego hipoteką, która in concreto może okazać się błędna.

$\mathrm{Z}$ tej perspektywy godnym rozważenia postulatem de lege ferenda wydaje się być wprowadzenie możliwości zasądzenia przez sąd dopłat uzależnionych od spełniania warunku zawieszającego w postaci spłacenia kredytu przez małżonków ${ }^{15}$. Możliwość wprowadzenia wskazanej zmiany nie powinna budzić wątpliwości od strony konstrukcyjnej. W doktrynie

\footnotetext{
${ }^{15}$ Dopłaty i spłaty nie mogą być obecnie zasądzone warunkowo. Zob. post. SN z 20.1.1984 r., III CRN 336/83, LEX nr 1633165 oraz wyr. SN z 30.9.2016 r., I CSK 702/15, LEX nr 2188613.
} 
pojawił się już bowiem pogląd, że zasądzenie dopłat warunkowych jest możliwe, jeżeli uczestnicy postępowania podziałowego (uprawniony i zobowiązany do dopłat) wyrażają na to zgodę, co wyprowadza się a maiori ad minusz faktu dopuszczalności zrzeczenia się spłat lub dopłat ${ }^{16}$. Przyznanie możliwości wydania tego typu orzeczenia przez sąd niewątpliwie pozwoliłoby na lepszą realizacje celów postępowania działowego, które ściśle wiążąc się z problematyką współwłasności oraz wspólności majątku pozostaje - jak wskazano w motto niniejszej glosy - źródłem sporów.

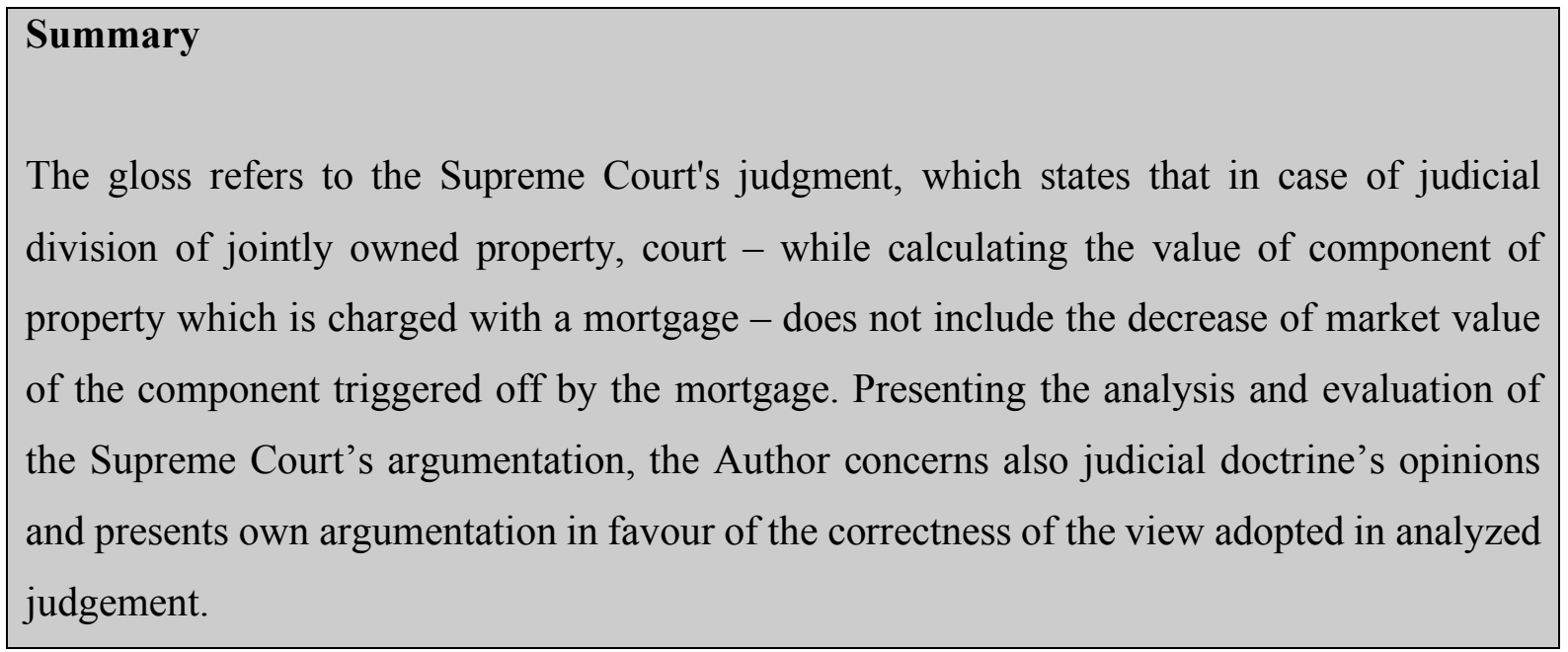

\section{Adrian Zbrojewski}

Doktorant w Katedrze Prawa Gospodarczego i Handlowego na Wydziale Prawa i Administracji Uniwersytetu Łódzkiego, aplikant radcowski.

\footnotetext{
${ }^{16}$ P. Księżak [w:] Kodeks cywilny. Komentarz. Tom II. Własność i inne prawa rzeczowe. Ustawa o księgach wieczystych i hipotece (art. 2-22, 65-1111). Ustawa o zastawie rejestrowym i rejestrze zastawów, red. K. Osajda, Warszawa 2017, s. 330-331.
} 